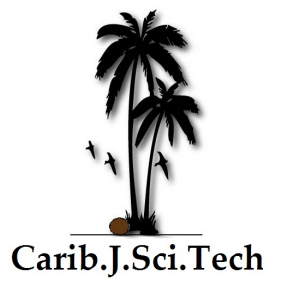

\title{
Adsorption Potentialities of Bio-Sorbents Derived from Pomegranate in the Removal of Methyl Red Dye from Polluted Waters
}

\author{
Authors \& Affiliation: \\ Venkata Ramana Kokkiligadda ${ }^{1, *}$, \\ Rama Krishna Veni Pokala ${ }^{2}$, \\ Anusha Karumuri $^{3}$ \\ Hari Babu Bollikola ${ }^{1}$ \\ ${ }^{1}$ Department of Chemistry, Acharya \\ Nagarjuna University, Andhra Pradesh- \\ 522510, India. \\ ${ }^{2}$ Department of Applied Sciences and \\ Humanities, Sasi Institute of Technology \\ $\&$ Engineering, Tadepalligudem, \\ Andhra Pradesh, India. \\ ${ }^{3}$ Department of Chemistry, Govt. \\ College of Women s (GCWA), Guntur, \\ Andhra Pradesh, India.
}

\section{Corresponding Author}

Venkata Ramana Kokkiligadda

Email:prasanthikvr@gmail.com

Received Date: $18^{\text {th }}$ Oct' 2020

Accepted Date: $2^{\text {nd }}$ Dec' 2020

(C) 2020.The Authors. Published under Caribbean Journal of Science and Technology

\begin{abstract}
:
Synthetically prepared simulated waste waters was used for exploring sorption abilities of the sorbent substance obtained from barks and leaves of Pomegranate towards Methyl Red. Factors that affect adsorption like temperature, adsorbent dosage, starting dye concentration and time of contact were evaluated. Four adsorption isotherms namely Freundlich, Langmuir, Temkin and DubininRadushkevich were analyzed for studying equilibrium of adsorption. Rate and adsorption process kinetics were identified by applying Weber and Morrish intraparticle diffusion, Bangham's pore diffusion, pseudo-first-order, pseudosecond-order and Elovich equations.Fivefold excess of common ions interference in natural aquifers, have been analyzed. Cations such as $\mathrm{Ca}^{2+}, \mathrm{Mg}^{2+}$ and $\mathrm{Cu}^{2+}$ have shown little interference but $\mathrm{Fe}^{2+}$ and $\mathrm{Zn}^{2+}$ ions combinedly maintained maximum withdrawal of the dye. Procedures that were developed could be successfully applied to few industrial effluents.Data collected out of experimentation was suitable to the pseudo-First order kinetic standard. Correlation coefficient $\left(\mathrm{R}^{2}\right)$ and dimensionless separation factor $\left(\mathrm{R}_{\mathrm{L}}\right)$ valuesconformed that adsorption process follows Langmuir adsorption indicating single layer formation. The adsorption process had good correlation coefficient equivalence with pseudo-second-order model. Temperature effect was also studied.
\end{abstract}

Keywords: Methyl Red(MeR); Equilibrium model; Bio-sorbent; Kinetics; Adsorption isotherms; Pomegranate.

\section{Introduction:}

Water infected by contaminates that degrade the water quality is known as polluted water. It includes the discharge of noxious materials, heavy metals, dyes,infectious germs, aerobic bacteria, solvable substances, etc. The main causes for dye pollution are the materials discharged from fibre, cloth, fur, food stuffs, cosmetics, dye, pulp and papermanufacturing industries [1]. Artificial dyes aren't consistently susceptibletowardbiodegradation, non-conventional biological waste water treatment, and protest towards microbial azo-dyes that are widely used in several industries, are the biggest class with diverse range of colours and structures. The need for the treatment of waste water contaminated with dye, arose because of environmental impact [2].The usual waste water treatment is generally not effective and various chemical, physical and biological treatments or their combinations are being studied at present [3, 4]. Silica[5],alumina, with activated carbon [6] act as common adsorbents to treat waste water asevidenced by numerous researchers $[7,8]$. 
To remove dyes from waste water, various techniques have been developed. Electro-kinetic coagulation, ionexchange, membrane filtration, electrochemical oxidation and photo-catalytic degradation process [9-15] are the widely used techniques, but these methods are costly and may not be favourable in large scale treatments.

The current research is a thorough study on optimizing extraction requisites like sorption quiddity of active biosorbent concerningMR - methyl red by varying contact time, $\mathrm{pH}$, dose level of adsorbent, MR dye (methyl red) initial concentration, temperature, and ions that areinterfering. The Freundlich, Langmuir, Temkin and DubininRadushkevich (D-R) isotherms and kinetics of adsorption processes were used to analyze pseudo first-order, pseudo second-order, Weber and Morrish intraparticle diffusion, Bangham's pore diffusion and Elovich equations. Temperature effect on adsorption was also studied.For removal of MR from polluted waste water samples with biomaterials extracted from Pomegranate's barks \& leaves, the developed methodologies have been applied. Pomegranate is a commonly available plant, which is used in fencing property perimeter in Kerala.

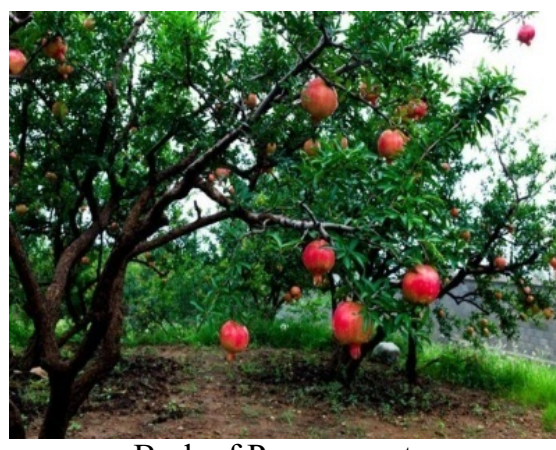

Bark of Pomegranate

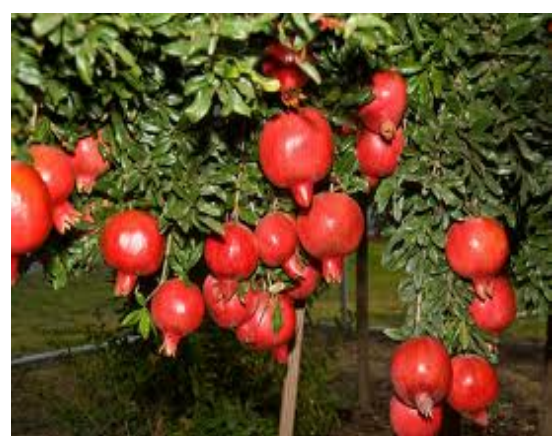

Leaves of Pomegranate

Figure 1: Bark and leaves of Pomegranate

\section{Materials and Methods:}

Chemicals-Chemicals of analytical reagent grade were utilized.

MR's Stock solution-Required amount of analytical reagent grade MR dye was dissolved in double distilled water to prepare $100 \mathrm{mg} / \mathrm{L}$ of MR solution. It was diluted as of required.

Preparation of Adsorbent-Pomegranate leaves and bark were gathered, chopped into tiny pieces, cleaned by double water, and left to dry for 2 days in the sun. We investigated the sorption capacities of plant materials against Methyl Red \& found favourable findings.

Adsorption Experiment-For extraction process the batch system has been adopted [16-18]. The adsorbents were weighed carefully and taken into well cleaned $1 \mathrm{~L} / 500 \mathrm{~mL}$ stopper bottles that contain $500 \mathrm{~mL} / 250 \mathrm{~mL}$ of MR Dye solution of pre-decided concentrations. $\mathrm{pH}$ meter was used to adjust several starting $\mathrm{pH}$ values of the suspensions with dilute $\mathrm{HCl}$ or dilute $\mathrm{NaOH}$ solutions. Samples were shacked strenuously using mechanical shakers for allowing them to be in equilibrium up to required time. An aliquot of the sample was used to determine MR dye using Spectrophotometric method [19-20]. $\lambda$ max of the dye was found as $464.9 \mathrm{~nm}$ alsoat low concentrations law of Beers-Lambert obeyed. Optical density measurements were taken at $\lambda \max 464.9 \mathrm{~nm}$ by making use of UV-Visible Spectrophotometer of Systronics make. The optical density attained for un-known solution was compared with reference graphs of known concentrations of MR Dye using Least Squares method.

By using various physicochemical parameters, adsorbents - sorption characteristics were studied. MR dye percentage removal from simulated water samples at different $\mathrm{pH}$ values was studied in relation to time of equilibration at a permanent sorbent concentration. The results attained were shown in Figure 2-5 and 6.Extraction studies were made to determine the least dosage required for the maximum removal of the MRDye.Extraction 
percentage in relation to sorbent dosage was studied to determine optimum $\mathrm{pH}$ and equilibration times. The results attained were shown in the Figure 7.

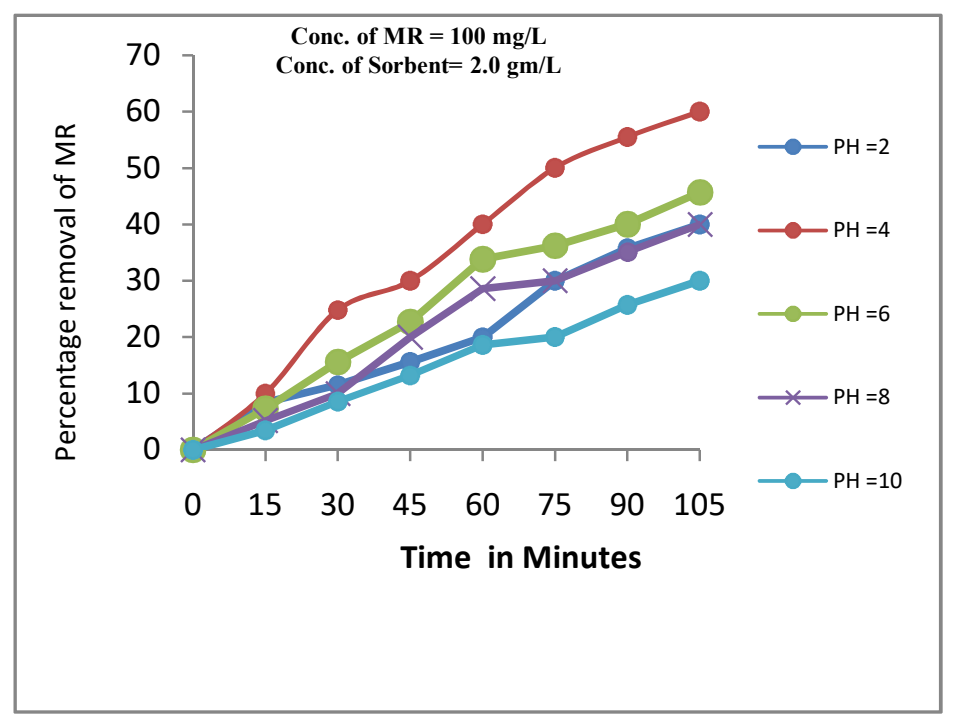

Figure 2:\% Removal of MRin relation to equilibration time at a fixed sorbent concentration from powder form of Pomegranate leaves

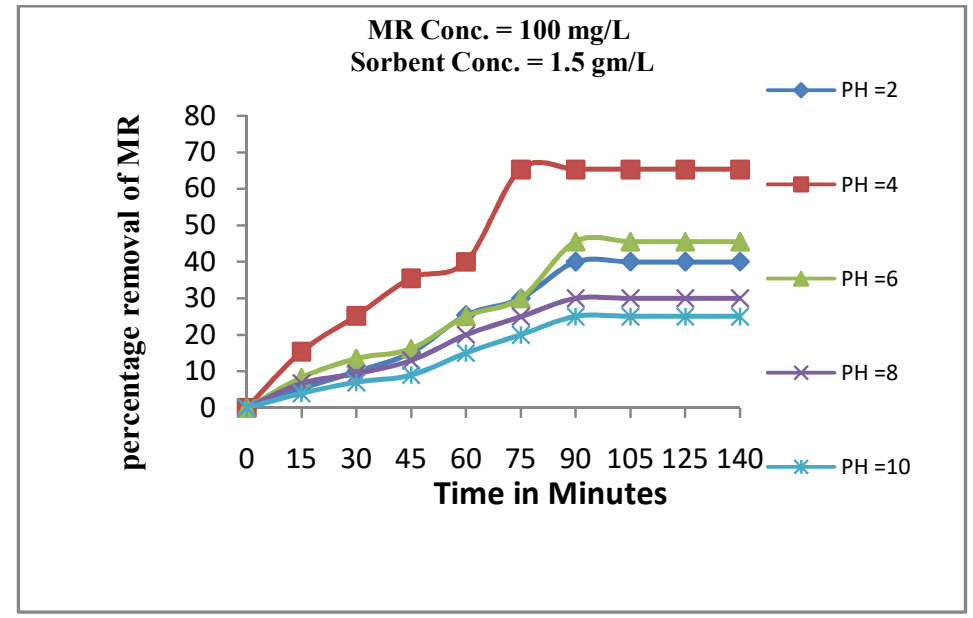

Figure 3:\% Removal of MR in relation to equilibration time at fixed sorbent concentration from ash of Pomegranate leaves

\section{Analysis of MR dye}

Following equations were used to determine the percentage removal and the amount of MR adsorbed (mg/g) -

$$
\text { Percentage of Removal }(\% \mathrm{R})=\frac{\mathrm{Ci}-\mathrm{Ce}}{\mathrm{Ci}} \times 100
$$


Amount of MR adsorbed $(\mathrm{qe})=\frac{\mathrm{Ci}-}{\mathrm{m}} \times \mathrm{V}$

Where, $\mathrm{C} i=$ Starting MR concentration in $\mathrm{mg} / \mathrm{L} ; \mathrm{Ce}=$ Equilibrium concentration of MR solution in $\mathrm{mg} / \mathrm{L}$; $\mathrm{m}=$ Adsorbent mass in gm; $\mathrm{V}=$ Volume of MR solution in liters

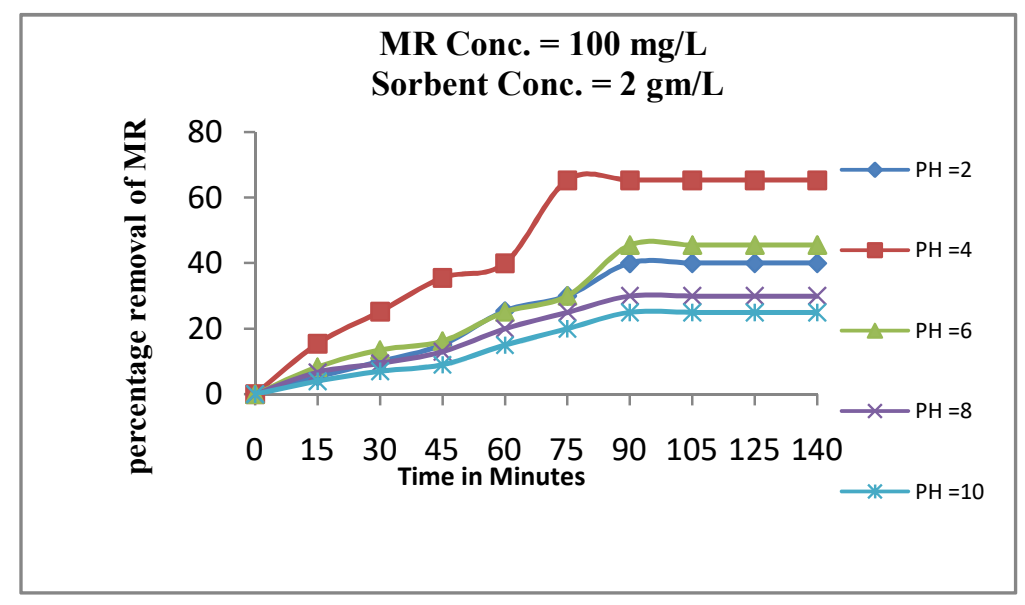

Figure 4:\% Removal of MR in relation to equilibration time at a fixed sorbent concentration from bark powder of Pomegranate

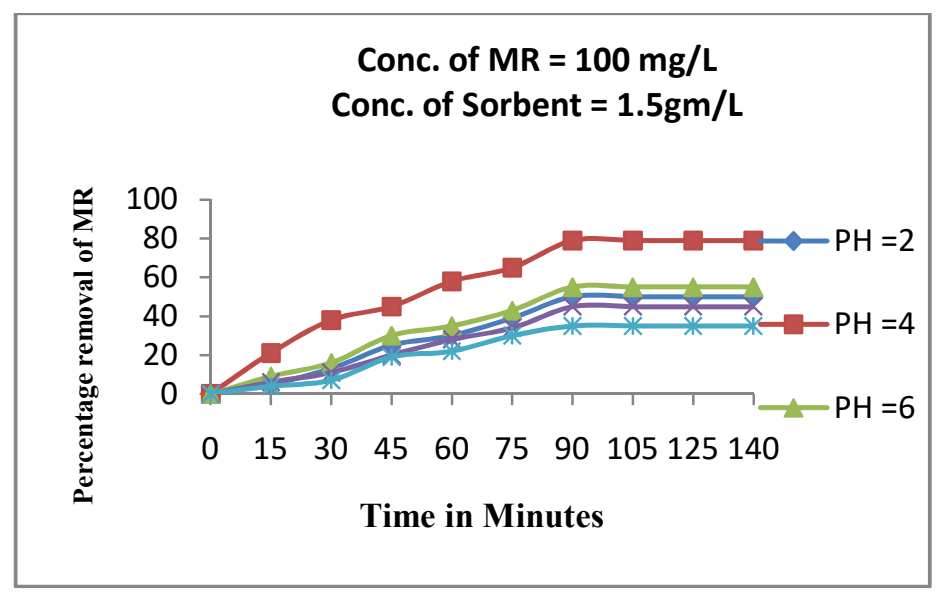

Figure 5:\% Removal of MRin relation to equilibration time at a fixed sorbent concentration from bark ash of Pomegranate

The above equations were used in the experiments done for determining several physical and chemical characteristics like weight of adsorbent, $\mathrm{pH}$ of the MR solution, MR solution strength, and equilibration time, particle size of the adsorbent, temperature and presence of foreign ions. 


\section{Effect of Co-Ions (Interfering Ions/Common ions)}

$\mathrm{NO}_{3}{ }^{-}, \mathrm{CO}_{3}{ }^{2-} \mathrm{SO}_{4}{ }^{2}-, \mathrm{Cl}^{-}, \mathrm{PO}_{4}{ }^{3-}, \mathrm{Ca}^{2+}, \mathrm{Mg}^{2+}, \mathrm{Fe}^{2+}, \mathrm{Cu}^{2+}$ and $\mathrm{Zn}^{2+}$ are the interfering ions chosen for study were the common ions present in natural water.

MR dye and synthetic mixtures common ions were prepared and the strength of the foreign ion was kept at fivefold excess than the dye strength. $500 \mathrm{~mL}$ of this solution was transferred into Stoppard bottles and ideal amount of accurately weighed adsorbents were added.Ideal $\mathrm{pH}$ was adjusted with dilute $\mathrm{HCl}$ or dilutes $\mathrm{NaOH}$ using $\mathrm{pH}$ meter. Mechanical shakers were used to shake the samples at regular intervals and small amount of the samples were estimated for MR dye after filtration and extraction percentage was determined.

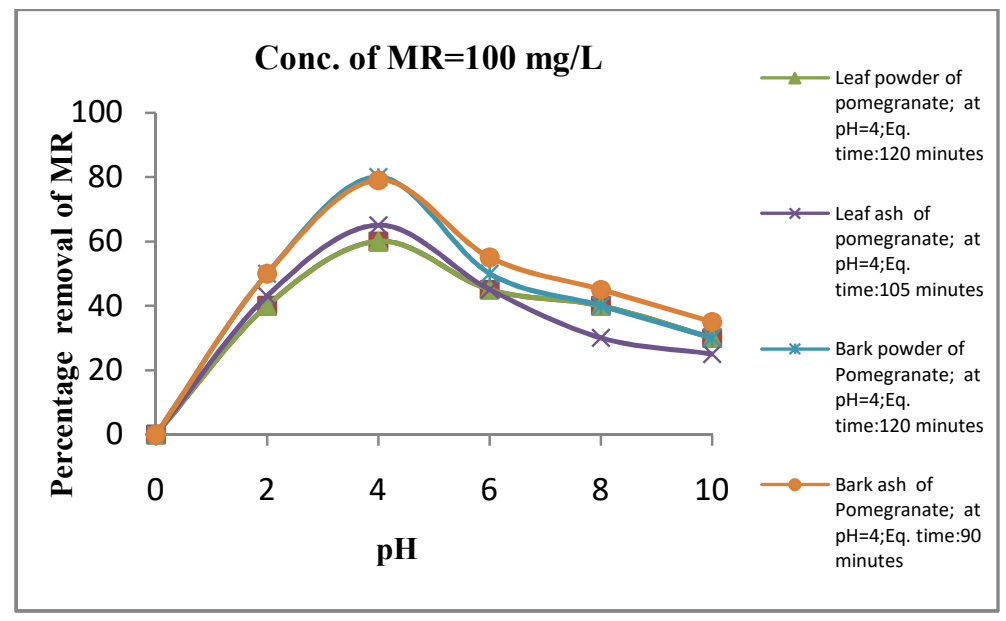

Figure 6:\% Removal of Methyl Red at different $\mathrm{Ph}$

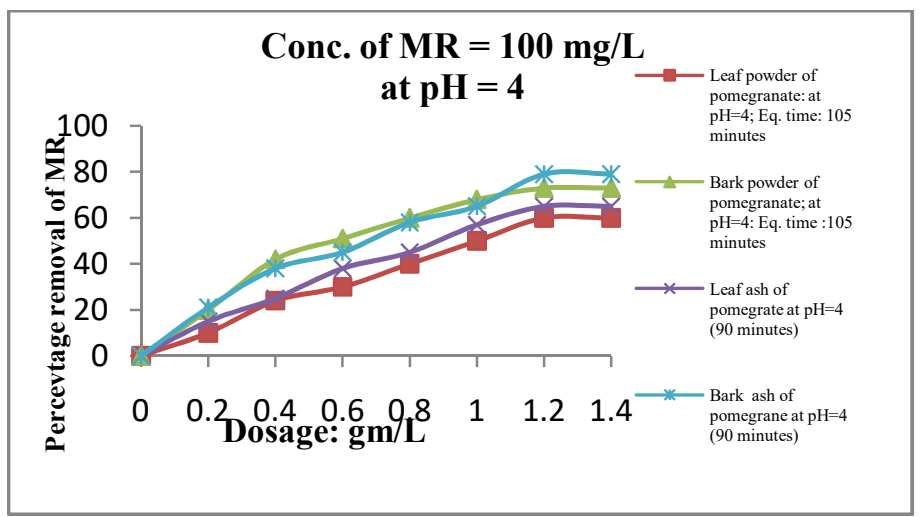

Figure 7:\% Removal of Methyl Redin relation to sorbent dosage

\section{Results and Discussion:}

The sorbent materials derived from Pomegranate plant were determined in relation to several physicochemical characters like $\mathrm{pH}$, equilibration time and sorption abilities for extractability of MR Figure 2-5, Figure 6 and Figure 7. The results of adsorption isotherm curves, kinetic parameter graphs and adsorption temperature graphs are given in the Tables 1-10. 
Table 1:Freundlich Isotherm

\begin{tabular}{|c|c|c|c|c|}
\hline S.No. & Name of Sorbent & Intercept & Slope & $\mathbf{R}^{\mathbf{2}}$ \\
\hline 1a & Leaves Powder of Pomegranate (LPOP) & 1.0107 & 0.3616 & 0.9384 \\
\hline 1b & Leaves ash of Pomegranate (LAOP) & 1.148 & 0.3363 & 0.9945 \\
\hline 1c & Bark Powder of Pomegranate (BPOP) & 1.0282 & 0.4077 & 0.9965 \\
\hline 1d & Bark ash of Pomegranate (BAOP) & 1.19 & 0.3821 & 0.9962 \\
\hline
\end{tabular}

Table 2: Langmuir Isotherm

\begin{tabular}{|c|c|c|c|c|c|}
\hline Sl. No & Name of Sorbent & $\mathbf{R}_{\mathbf{L}}$ & Slope & Intercept & $\mathbf{R}^{\mathbf{2}}$ \\
\hline 2a & LPOP & 0.0200 & 0.0031 & 0.0634 & 0.9964 \\
\hline 2b & LAOP & 0.0267 & 0.0220 & 0.0605 & 0.9872 \\
\hline 2c & BPOP & 0.0320 & 0.0245 & 0.0811 & 0.9813 \\
\hline 2d & BAOP & 0.0219 & 0.0206 & 0.0463 & 0.9832 \\
\hline
\end{tabular}

Table 3: Temkin Isotherm Results of Temkin Isotherm

\begin{tabular}{|c|c|c|c|c|c|}
\hline Sl. No. & Name of Sorbent & $\mathbf{b}$ & Slope(B) & Intercept & $\mathbf{R}^{2}$ \\
\hline 3a & LPOP & 43.9127 & 5.6799 & 11.915 & 0.9769 \\
\hline 3b & LAOP & 36.1421 & 6.9011 & 16.668 & 0.9574 \\
\hline 3c & BPOP & 36.8637 & 6.766 & 12.775 & 0.9418 \\
\hline 3d & BAOP & 32.9489 & 7.5699 & 19.329 & 0.9406 \\
\hline
\end{tabular}

Table 4:Dubinin-Radushkevich

\begin{tabular}{|c|c|c|c|c|c|}
\hline Sl. No. & Name of Sorbent & $\mathbf{E}$ & Slope & Intercept & $\mathbf{R}^{2}$ \\
\hline $\mathbf{4 a}$ & LPOP & 4.0825 & $3 \times 10^{-8}$ & 0.855 & 0.816 \\
\hline $\mathbf{4 b}$ & LAOP & 1.000 & $2 \times 10^{-7}$ & 0.8131 & 0.501 \\
\hline $\mathbf{4 c}$ & BPOP & 5.0203 & $2 \times 10^{-8}$ & 0.859 & 0.697 \\
\hline $\mathbf{4 d}$ & BAOP & 7.0711 & $1 \times 10^{-8}$ & 0.907 & 0.728 \\
\hline
\end{tabular}

Table 5: Pseudo first Order

\begin{tabular}{|c|c|c|c|c|c|}
\hline Sl. No. & Name of Sorbent & $\mathbf{K}_{\mathbf{1}}$ & Slope & InterceptResult & $\mathbf{R}^{\mathbf{2}}$ \\
\hline $\mathbf{5 a}$ & LPOP & 0.0309 & 0.0134 & 1.6829 & 0.9363 \\
\hline $\mathbf{5 b}$ & LAOP & 0.0189 & 0.0082 & 1.6646 & 0.9673 \\
\hline $\mathbf{5 c}$ & BPOP & 0.0253 & 0.011 & 1.7867 & 0.8616 \\
\hline $\mathbf{5 d}$ & BAOP & 0.0235 & 0.0102 & 1.6897 & 0.982 \\
\hline
\end{tabular}


Table 6: Pseudo Second Order

\begin{tabular}{|c|c|c|c|c|c|}
\hline Sl. No. & Name of Sorbent & $\mathbf{K}_{\mathbf{2}}$ & Slope & Intercept & $\mathbf{R}^{2}$ \\
\hline $\mathbf{6 a}$ & LPOP & $9.8098 \times 10^{-5}$ & 0.014 & 1.998 & 0.925 \\
\hline $\mathbf{6 b}$ & LAOP & $3.6232 \times 10^{-4}$ & 0.020 & 1.104 & 0.951 \\
\hline $\mathbf{6 c}$ & BPOP & $2.0181 \times 10^{-5}$ & 0.007 & 2.428 & 0.375 \\
\hline $\mathbf{6 d}$ & BAOP & $1.6866 \times 10^{-4}$ & 0.013 & 1.002 & 0.921 \\
\hline
\end{tabular}

Table7: Weber and Morris

\begin{tabular}{|c|c|c|c|c|c|}
\hline Sl. No & Name of Sorbent & $\mathbf{K}_{\mathbf{0}}$ & Slope & Intercept & $\mathbf{R}^{\mathbf{2}}$ \\
\hline $\mathbf{7 a}$ & LPOP & 0.1678 & 1.112 & -2.619 & 0.986 \\
\hline $\mathbf{7 b}$ & LAOP & 0.2651 & 0.861 & -2.162 & 0.992 \\
\hline $\mathbf{7 c}$ & BPOP & 0.1932 & 1.048 & -2.478 & 0.953 \\
\hline $\mathbf{7 d}$ & BAOP & 0.2938 & 0.914 & -2.059 & 0.991 \\
\hline
\end{tabular}

Table 8:Bangham's pore diffusion

\begin{tabular}{|c|c|c|c|c|}
\hline Sl. No & Name of Sorbent & Slope & Intercept & $\mathbf{R}^{2}$ \\
\hline $\mathbf{8 a}$ & LPOP & 4.031 & -10.66 & 0.989 \\
\hline $\mathbf{8 b}$ & LAOP & 4.700 & -8.373 & 0.988 \\
\hline $\mathbf{8 c}$ & BPOP & 4.437 & -12.73 & 0.961 \\
\hline $\mathbf{8 d}$ & BAOP & 5.212 & -7.903 & 0.991 \\
\hline
\end{tabular}

Table 9:Elovich

\begin{tabular}{|c|c|c|c|c|c|}
\hline Sl. No.. & Name of Sorbent & A & Slope & Intercept & $\mathbf{R}^{2}$ \\
\hline 9a & LPOP & 1.1294 & 12.50 & -30.05 & 0.964 \\
\hline 9b & LAOP & 1.1577 & 13.76 & -28.30 & 0.963 \\
\hline 9c & BPOP & 1.1785 & 14.10 & -35.01 & 0.887 \\
\hline 9d & BAOP & 2.1257 & 15.36 & -30.38 & 0.979 \\
\hline
\end{tabular}

Table 10: Effect of temperature

\begin{tabular}{|c|c|c|c|c|c|}
\hline SI. No & Temperature (K) & $\mathbf{\Delta H}(\mathbf{~ k J} / \mathbf{m o l})$ & $\mathbf{\Delta S}(\mathbf{J} / \mathbf{m o l} / \mathbf{K})$ & $\mathbf{\Delta G}(\mathbf{k J} / \mathbf{m o l})$ & $\mathbf{R}^{\mathbf{2}}$ \\
\hline $\mathbf{1 0 a}$ & LPOP & 18.5402 & 0.0536 & -0.9594 & 0.975 \\
\hline $\mathbf{1 0 b}$ & LAOP & 18.4321 & 0.0573 & -0.3623 & 0.975 \\
\hline $\mathbf{1 0 c}$ & BPOP & 21.0178 & 0.0667 & -0.8606 & 0.985 \\
\hline $\mathbf{1 0 d}$ & BAOP & 25.9563 & 0.0845 & -1.7597 & 0.978 \\
\hline
\end{tabular}




\section{The following observations have been reported}

\section{Equilibration time}

Adsorbent's extractability rises at certain $\mathrm{pH}$ with time but at equilibration time, it remains constant indicating the approach of equilibrium state i.e., no further adsorption takes place after certain equilibration time (Figure 2-5).

In LPOP, the percentage removal of MR was found to be $10 \%$ at $15 \mathrm{~min}, 24.8 \%$ at $30 \mathrm{~min} 30.0 \%$ at $45 \mathrm{~min}$ and $40.0 \%$ at $60 \mathrm{~min}, 50.0 \%$ at $75 \mathrm{~min}, 55.5 \%$ at $90 \mathrm{~min} 60.0 \%$ at $105 \mathrm{~min}$ or above at pH: 4 . Similarly the percentage removal of MR using the bark and ashes of Pomegranate was determined.

\section{pHeffect}

Removal of MR was found with respect to $\mathrm{pH}$ of the agitating equilibration time for certain adsorbent. Figure 6 shows maximum removal of $35.8 \%$ at $\mathrm{pH}: 2 ; 55.5 \%$ at $\mathrm{pH}: 4 ; 40.0 \%$ at $\mathrm{pH}: 6 ; 35.1 \%$ at $\mathrm{pH}: 8$ and $25.7 \%$ at $\mathrm{pH}$ : 10, after an equilibration span of $90 \mathrm{~min}$ for LPOP. With the bark powder of pomegranate (BPOP) the percentage of extraction was found to be $50.0 \%$ at $\mathrm{pH}: 2 ; 75.2 \%$ at $\mathrm{pH}: 4 ; 55.9 \%$ at $\mathrm{pH}: 6 ; 45.4 \%$ at $\mathrm{pH}: 8$ and $30.0 \%$ at $\mathrm{pH}: 10$ after an equilibration span of $125 \mathrm{~min}$. Similarly the percentage extraction of MR, by using the pomegranate ashes has been studied. The optimum time of equilibration needed for maximum removal of MRwas found to be 90 min at pH: 4, while with the BPOP, the equilibration spanwas found to be $125 \mathrm{~min}$.

\section{Sorbent Concentration}

For the maximum extractability of the MR, the optimum sorbent concentration requiredfor leaves and bark powders of Pomegranate was1.0 gm/500 mL.

\section{Interfering Ions}

The consequences of MR extractability in proximity of fivefold overabundance of principalsubstances found in characteristic waters likeSO${ }_{4}{ }^{2}, \mathrm{Cl}^{-}, \mathrm{CO}_{3}{ }^{2-}, \mathrm{PO}_{4}{ }^{3-}, \mathrm{MR}, \mathrm{Ca}^{2+}, \mathrm{Mg}^{2+}, \mathrm{Fe}^{2+}, \mathrm{Cu}^{2+}$ and $\mathrm{Zn}^{2+}$, was contemplated and displayed in Table 11. Negatively charged ionsshowedless impact on extractability rate of MR with the sorbents of current work at the absolute states of equilibration time, $\mathrm{pH}$ and sorbent focus.

Table 11: Interfering ions effect on MR extractability with various bio-sorbents: 63 - 99 in the middle of values

\begin{tabular}{|c|c|c|c|c|c|c|c|c|c|c|c|c|}
\hline \multirow[b]{2}{*}{ S.No } & \multirow[b]{2}{*}{$\begin{array}{l}\text { Adsorbent and } \\
\text { its concentration }\end{array}$} & \multirow{2}{*}{$\begin{array}{c}\text { Maximum } \\
\text { Extractability at } \\
\text { optimum } \\
\text { conditions }\end{array}$} & \multicolumn{10}{|c|}{$\begin{array}{l}\text { \% of MR At optimal conditions, fivefold excess of interfering ions extraction.: } \\
\text { Conc. of MR: } 100 \mathrm{ppm} \text { at } \mathrm{pH}: 4\end{array}$} \\
\hline & & & $\begin{array}{c}\mathrm{SO}_{4}{ }^{2-} \\
\%\end{array}$ & $\begin{array}{c}\mathrm{PO}_{4}{ }^{3-} \\
\%\end{array}$ & $\begin{array}{c}\mathrm{Cl}^{-} \\
\%\end{array}$ & $\begin{array}{c}\mathrm{CO}_{3}{ }^{2-} \\
\%\end{array}$ & $\begin{array}{l}\mathbf{F}^{-} \\
\%\end{array}$ & $\mathrm{Fe}^{2+} \%$ & $\begin{array}{c}\mathrm{Ca}^{2+} \\
\%\end{array}$ & $\begin{array}{c}\mathbf{M g}^{2+} \\
\%\end{array}$ & $\begin{array}{c}\mathrm{Cu}^{2+} \\
\%\end{array}$ & $\begin{array}{c}\mathrm{Zn}^{2+} \\
\%\end{array}$ \\
\hline 11 & LPOP: $\quad 2.0 \mathrm{~g} / \mathrm{L}$ & $\begin{array}{l}60.0 \% ; \mathrm{pH}: 4,105 \\
\text { min }\end{array}$ & 83.0 & 99.2 & 92.0 & 88.9 & 91.2 & 86.6 & 83.4 & 66.5 & 89.4 & 93.0 \\
\hline 22 & BPOP: $2.0 \mathrm{~g} / \mathrm{L}$ & $\begin{array}{l}75.0 \% ; \mathrm{pH}: 4,125 \\
\text { min }\end{array}$ & 92.0 & 77.5 & 84.2 & 87.0 & 86.0 & 82.5 & 67.5 & 74.0 & 68.0 & 63.0 \\
\hline 33 & LAOP: $1.5 \mathrm{~g} / \mathrm{L}$ & $\begin{array}{c}65.3 \% \\
\mathrm{pH}: 4,90 \mathrm{~min}\end{array}$ & 79.2 & 81.4 & 83.7 & 86.5 & 85.2 & 81.3 & 67.1 & 73.8 & 67.6 & 62.0 \\
\hline 44 & BAOP: $1.75 \mathrm{~g} / \mathrm{L}$ & $\begin{array}{c}79.0 \% \\
\mathrm{pH}: 4,90 \mathrm{~min}\end{array}$ & 92.5 & 76.2 & 86.1 & 78.5 & 92.1 & 98.5 & 68.3 & 74.0 & 68.0 & 63.0 \\
\hline
\end{tabular}

\section{Adsorption Isotherms}


Freundlich [21], Langmuir [22], Temkin [23], and Dubinin-Radushkevich [24] are well- acquainted adsorption isotherm models that assessed the relationship combining the MR fixations leavings in the mass answer to estimate MR adsorbed there at situating interface so at given temperature.

Freundlich condition's straight type: $\quad \log \left(\mathrm{q}_{\mathrm{e}}\right)=\log \mathrm{k}_{\mathrm{f}}+\frac{1}{n} \log \mathrm{C}_{\mathrm{e}}$

Langmuir equation in linear form; $\left.\mathrm{C}_{\mathrm{e}} / \mathrm{q}_{\mathrm{e}}\right)=\left(\mathrm{a}_{\mathrm{L}} / \mathrm{k}_{\mathrm{L}}\right) \mathrm{C}_{\mathrm{e}}+1 / \mathrm{k}_{\mathrm{L}}$

As laid out by Hall et al. [25], adsorption phenomena character was annoyingin $R_{L}>1$, straight in $R_{L}=1$, great in $1>R_{L}>0$ and unalterable in $R_{L}=0$ alsoLangmuir isotherm model's critical component was identified thru measureless schismfigure, $\mathrm{R}_{\mathrm{L}}=1 /(1+\mathrm{aLCi})$. Adsorption isotherms outputs were shown in Tables 1 and 2 . The closeness of $\mathrm{R}^{2}$ values to oneindicates the materialness of 2 adsorption isotherms affirmingadsorbent's diversified surface and MR's single layer possibilityover bio-sorbent. The isotherm state's appropriateness is thought about from the connection coefficient $\left(\mathrm{R}^{2}\right)$. Regarding Freundlich isotherm with $\mathrm{R} 2=0.9965$ esteem, Langmuir isotherm with $\mathrm{R} 2=0.9964$ as well as dimensionless separation figure with $R L=0.0200$, the link coefficient estimation of leaves, bark dust, and fiery remnants of Pomegranate was determined to be about $0-1$. This indicates that Langmuir isotherm is more agreeable than Freundlich isotherm.

Linear form of Temkin equation: $\mathrm{q}_{\mathrm{e}}=\mathrm{B} \operatorname{lnCe}+\mathrm{B} \ln \mathrm{A}$, where $\mathrm{RT} / \mathrm{b}=\mathrm{B}$

Linear form of Dubinin-Radushkevich equation:lnq $\mathrm{q}_{\mathrm{e}}=-\beta \varepsilon^{2}+\ln \mathrm{qm}$

$$
\text { in which, } \varepsilon=\mathrm{RT} \ln \left(1+1 / \mathrm{C}_{\mathrm{e}}\right)
$$

Tables 3 and $\mathbf{4}$ exhibit the linear graphs of all these two adsorption isotherms with isothermal constants, as well as the correlation coefficient estimates.

The $\mathrm{R}^{2}$ - relationship coefficients are close to one. Temkin amiability of sorption, $\mathrm{B}=7.5699 \mathrm{~J} / \mathrm{mol}$ was computed from liability of direct plot of Temkin [26, 27], and mean free vitality of Dubinin-Radushkevich $E=\sqrt{ }(1 / 2 \beta)$, [28] was found as $\mathrm{E}=7.0711 \mathrm{KJ} / \mathrm{mol}$. In current extraction investigation $\mathrm{E}<8 \mathrm{~kJ} / \mathrm{mol}$, relates to physical adsorption [29] profuse adsorptions also particle trade. Physical adsorption was called indefiniteadsorption that takes place after long range powerless van der Waals force in the middle of MR and adsorbent. According to Atkins [30], Physical adsorption is nothing but mean free vitality (E) plus sorption warms (B) of lesser than $20 \mathrm{~kJ} / \mathrm{mol}$.

\section{Adsorption Kinetics}

The rate \& energy of MR adsorption here to bio-sorbent acquired in Pomegranate were contrasted to pseudo firstorder exhibit [31-32], pseudo second-order exhibit [32-33], Weber and Morris intra-particle dissemination show [34], Bangham's pore dispersion display [35], as well as Elovich state [36-37].

The pseudo $1^{\text {st }}$-orderequation: $\log (\mathrm{qe}-\mathrm{qt})=\log \mathrm{q}_{\mathrm{e}} \frac{k 1}{2.303} \times t$

The pseudo $2^{\text {nd }}$-order equation:t/qt $=\frac{1}{k 2 q e 2}+(1 / \mathrm{qe}) \mathrm{t}$

Weber \& Morris diffusion equation for intraparticle: $\mathrm{q}_{\mathrm{t}}=\mathrm{k}_{\mathrm{ip}} \mathrm{t}^{1 / 2}+\mathrm{c}$

Bangham's pore diffusion equation:log $\left[\log \left(\mathrm{C}_{\mathrm{i}} / \mathrm{C}_{\mathrm{i}}-\mathrm{q}_{\mathrm{t}} \mathrm{m}\right)\right]=\log (\mathrm{ko} / 2.303 \mathrm{~V})+\alpha \log (\mathrm{t})$

Elovich equation: $\mathrm{q}_{\mathrm{t}}=1 / \beta \ln (\alpha \beta)+1 / \beta \ln (\mathrm{t})$

Graphs of the above said dynamic models, rate constants and correlation coefficients were displayed in Tables 59.Among the five dynamic models, leaves, bark powder ash of Pomegranate's $\mathrm{R}^{2}$ determination for Weber and Morris is $R^{2}=0.991$, Bangham's pore dispersion is $R^{2}=0.991$ pseudo first-arrange is $R^{2}=0.982$, pseudo secondarrange is $\mathrm{R}^{2}=0.951$ and Elovich demonstrate is $\mathrm{R}^{2}=0.979$. 


\section{Effect of Temperature}

By administering the extraction experiments at various temperatures of 298, 308, 318, and $328 \mathrm{~K}$ at absolute extraction states, the influence of temperature upon that MR's percent evaluation MR was studied: $\mathrm{pH}-4.0$; sorbent measurement - $3.0 \mathrm{mg} / \mathrm{L}$; contact time - $90 \mathrm{~min}$; particle determiner - 45 work; MR colour arrangement mixing - 100 $\mathrm{mg} / \mathrm{L}$; results plotted as $\ln (\mathrm{Kd}) \mathrm{Vs} 1 / \mathrm{T}$ as shown in Figure 8.

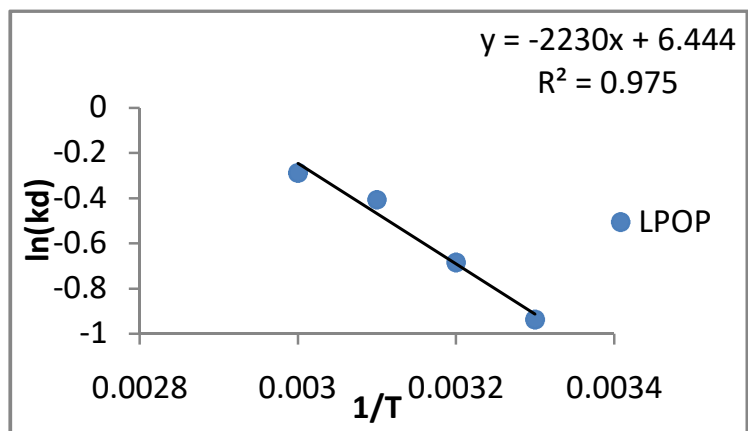

8(a)

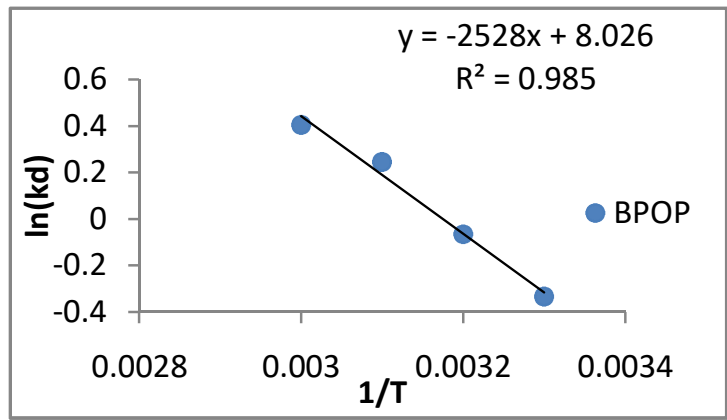

8(c)

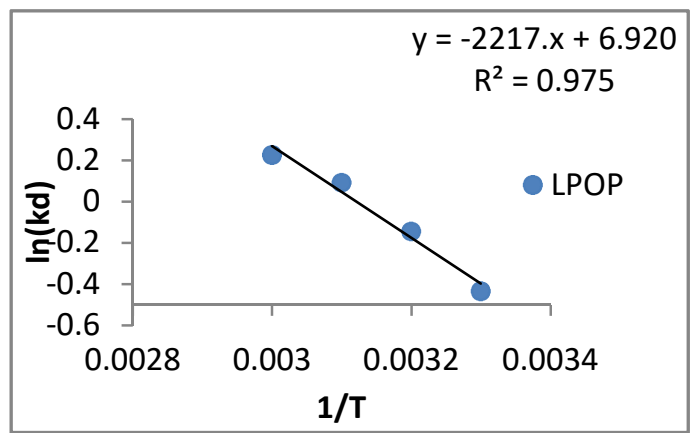

8(b)

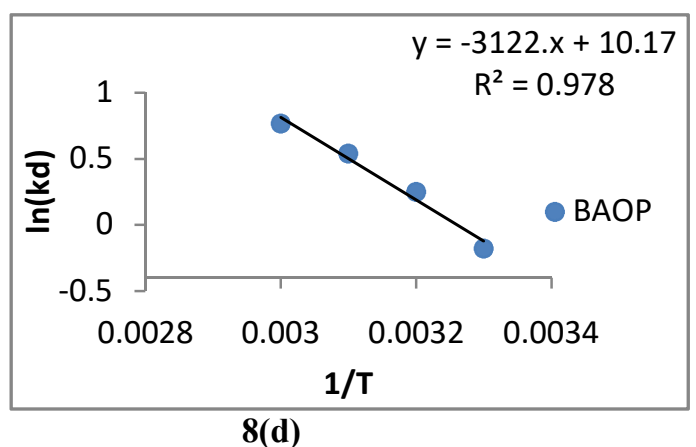

Figure 8 Effect of temperature

Thermodyanamic characters of the adsorption method, like variation in free vitality $(\Delta \mathrm{G}) \mathrm{kJ} / \mathrm{mole}$, enthalpy variation - $\Delta \mathrm{H} \mathrm{kJ} /$ mole also entropy variation - $\Delta \mathrm{S} \mathrm{KJ} /$ mole too were found in varyingbyusing the conditions [38-40].

$$
\begin{aligned}
& \Delta G=-R T \ln K_{d} \\
& \ln K_{d}=\Delta S / R-\Delta H / R T \\
& \Delta G=\Delta H-T \Delta S
\end{aligned}
$$

Here, $\mathrm{Kd}$ - dissemination adsorption coefficient, $\mathrm{q}_{\mathrm{e}}$ - amount of MR adsorbed on adsorbent per lit. of deposition at harmony, $\mathrm{C}_{\mathrm{e}}$ - the MR colour deposition's steadiness centralization, $\mathrm{T}$ - outright temperature in Kelvin and $\mathrm{R}$ - the gas steady.

$\Delta \mathrm{G}, \Delta \mathrm{H}$ and $\Delta \mathrm{S}$ are the adaptations in free vitality, enthalpy and entropy.

The approximations of $\Delta \mathrm{H}$ and $\Delta \mathrm{S}$ were obtained from slope and apprehend of a plot in the middle of $\ln (\mathrm{Kd})$ and $1 / \mathrm{T}$ and $\Delta \mathrm{G}$ characters were acquired from the relation $\Delta \mathrm{G}=\Delta \mathrm{H}-\mathrm{T} \Delta \mathrm{S}$ and classified [41-42]. It has been observed that with rise in temperature from $298-328 \mathrm{~K}, 25-55^{\circ} \mathrm{C}$, maximum extraction of MR takes place at $328 \mathrm{~K}$. 
The results shown in Table 10, indicates that the determinations of $\Delta \mathrm{H}$ are possible, thereby illustrates the physical sorption and endothermic nature of adsorption [43]. Endothermic nature of adsorption process is shown by the 2 values close to one. The constructive determinations of $\Delta S$ illustrate enlarge matter and deformity at the powerful ordering interface of MR colour with adsorbent $[44,45]$.The obstruction findings of $\Delta G$ show that the adsorption method's spontaneous process indicates that the adsorptive strength is sufficiently solid to overcome the potential impediment $[46,47]$.

\section{Applications of the developed Bio-Sorbents}

The acceptability of the strategies generated with the latest bio-sorbents obtained from Pomegranate for expelling MR dye in waste waters, was tried with few authentic sewage/emanating tests of a small number of businesses. At that moment the samples were exposed to withdrawal of the colour using the bio-sorbents generated as a segment of present study at absolute states of extraction. The end results acquired were exhibited in Table 12.

Table $12 \%$ Removal of MR from effluviumusing bio-sorbents proceeded in current work 80 - 90 middlevalues

\begin{tabular}{|c|c|c|c|c|c|c|}
\hline & \multicolumn{5}{|c|}{ \% Removal of MeR in varied samples } \\
\cline { 2 - 6 } & $\begin{array}{c}\text { Sample -1 } \\
\text { Delivered } \\
\text { with 10.0 } \\
\text { ppm MR } \\
\text { dye }\end{array}$ & $\begin{array}{c}\text { Sample -2 } \\
\text { Delivered } \\
\text { with 15.0 } \\
\text { ppm MR } \\
\text { dye }\end{array}$ & $\begin{array}{c}\text { Sample -3 } \\
\text { Delivered } \\
\text { with } 20.0 \\
\text { ppm MR } \\
\text { dye }\end{array}$ & $\begin{array}{c}\text { Sample -4 } \\
\text { Delivered } \\
\text { with } 25.0 \\
\text { ppm MR } \\
\text { dye }\end{array}$ & $\begin{array}{c}\text { Sample -5 } \\
\text { Delivered } \\
\text { with 30.0 } \\
\text { ppm MR } \\
\text { dye }\end{array}$ & $\begin{array}{c}\text { Sample -6 } \\
\text { Delivered } \\
\text { with 35.0 } \\
\text { ppm MR } \\
\text { dye }\end{array}$ \\
\hline $\begin{array}{c}\text { Powder of } \\
\text { Pomegranate leaves: } \\
2.0 \text { g/L }\end{array}$ & $83.5 \%$ & $89.1 \%$ & $86.5 \%$ & $88.3 \%$ & $87.4 \%$ & $82.1 \%$ \\
\hline $\begin{array}{c}\text { Powder of } \\
\text { Pomegranate bark: } \\
2.0 \text { g/L }\end{array}$ & $89.1 \%$ & $88.2 \%$ & $85.2 \%$ & $86.4 \%$ & $88.2 \%$ & $85.5 \%$ \\
\hline $\begin{array}{c}\text { Ashes of } \\
\text { Pomegranateleaves: } \\
1.75 \mathrm{~g} / \mathrm{L}\end{array}$ & $88.5 \%$ & $82.3 \%$ & $86.4 \%$ & $81.5 \%$ & $85.3 \%$ & $84.6 \%$ \\
\hline $\begin{array}{c}\text { Ashes of } \\
\text { Pomegranate bark: }\end{array}$ & $86.3 \%$ & $86.5 \%$ & $84.4 \%$ & $88.3 \%$ & $89.5 \%$ & $83.5 \%$ \\
\hline $1.5 \mathrm{~g} / \mathrm{L}$
\end{tabular}

\section{Conclusion:}

The circumstances for the majority uttermost removal of MR at lowest measurement and time of equilibration were upgraded. At pH: 4 the leaves and bark of Pomegranatehave shown reasonable bias MR. Sorbent quantity and time needed for greatest expulsion of MR is low for the blazing leftovers than with the raw powder of the plant substances. Fivefold abundance of normal negative ions found in common waters, haven't interfere the withdrawal of $\mathrm{MR}$ at absolute conditions of $\mathrm{pH}$, equilibration time and sorbent focus. Cations like $\mathrm{Ca}^{2+} \mathrm{Mg}^{2+}$ and $\mathrm{Cu}^{2+}$ have illustrated little obstruction, whereas $\mathrm{Fe}^{2+}$ and $\mathrm{Zn}^{2+}$ have collectively shown the most extreme removal of the colour.

The four Isotherms, the interconnection coefficient determination of leaves, bark powders and fiery debris of Pomegranate for the large interconnection coefficient for Freundlich isotherm esteem, Langmuir isotherm and indefinite splitting calculateisperceivedas a part in0-1 span, illustrate the favourabilityof Langmuir isotherm upon Freundlich isotherm. The five dynamic models, Weber and Morris' interconnectivity coefficient determination for leaves, bark powders, with fiery remnants of Pomegranate, and Bangham's pore dispersion exhibit pseudo first- 
order, pseudo second-order, and Elovich displays, respectively. It illustrates that pseudo second-order model is preeminently suited to the examined data of the current contemplate adsorption substructure. The determinations of $\Delta \mathrm{H}$ are definite; this displaysendothermic character and physical sorption of adsorption. The $\mathrm{R}^{2}$ readings close to, demonstrate the endothermic character of adsorption process. The productive determinations of $\Delta$ Smake evidenttheenlarged matter \& irregularity inMR colour's tough ordering interface with adsorbent.

\section{Acknowledgments}

Every author is thankful to Acharya Nagarjuna University, Andhra Pradesh, India for constant support and encouragement. The first author also thank Prof. Ravindranath, K.L.University, Guntur for encouragement.

\section{References:}

1. A. Bhatnagar and AK Jain. A comparative adsorption study with different industrial wastes as adsorbents for the removal of cationic dyes from water. J. Colloid. Interf. Sci., 2005, 281: 49-55.

2. KG Battacharyya and A Sharma. Kinetics and Thermodynamics of Methylene blue adsorption on neamleaf powder. Dyes Pigm., 2005, 65: 51-59.

3. T Robinson, B Chandran and P Nigam. Studies on the production of enzymes by white-rot fungi for thedecolourisation of textile Dye. Enzyme Microb. Technol., 2001, 29: 575-579.

4. V Shah and F Nerud. Lignin degrading system of white-rot fungi and its exploitation for dye decolorization. Can. J. Microbiol. 2002, 48: 857-870.

5. SYM Josefa and E De Oliveri. Heavy metals removal in industrial effluents by sequential adsorption treatment. Adv Environ Res., 2003, 7: 263-72.

6. DJ Malik, VJ Strelko, M Streat and AM Puziy. Characterization of novel modified active carbons and marine algal biomass for the selective adsorption of lead. Water Res., 2002, 369: 1527-1538.

7. FN Arslanoglue, F Kar and N Arslan. Adsorption of dark coloured compounds from peach pulp by using powdered activated carbon. J. Food Eng., 2005, 71: 156-163.

8. S Senthi Kumar, PR Varadarajab, K Pakordi and CV Subbhuraam. Adsorption of methylene blue onto Jute FiberCarbon : Kinetics and equilibrium Studies. J. Colloid Interface Sci., 2005, 284: 78- 82.

9. JA Laszlo. Preparing an ion exchange resin from sugarcane bagasse to remove reactive dye from wastewater. Text. Chem. Color., 1996, 28: 13-17.

10. AH Gemea, IA Mansour, RG El-Sharkawy and AB Zaki. Kinetics and mechanism of the heterogeneous catalyzed oxidative degradation of indigo carmine. J Mol Catal A Chem., 2003, 193: 109-120.

11. VL Grimau and MC Gutierrez. Decolorization of simulated reactive dyebath effluents by electrochemical oxidation assisted by UV light. Chemosphere. 2006, 62: 106-112.

12. C Hachem, F Bocquillon, O Zahraa, and M Bouchy. Decolorization of textile industry Wastewater by the photocatalytic degradation process. DyesPigm., 2001, 49: 117-125.

13. RL Cisneros, AG Espinoza and MI Litter. Photodegradation of an azo dye of the textile industry. Chemosphere, 2002, 48: 393-399.

14. VK Gupta and Suhas. Application of low-cost adsorbents for Dye removal-a review.J. Environ. Manage. 2009, 90: 2313-2342.

15. V Srivastava, ID Mall and IM Mishra. Equilibrium modelling of single and binary adsorption of cadmium and nickel onto bagasse fly ash. Chem. Eng. J. 2006, 117: 79-91.

16. RK Trivedy. Environmental Publications. Pollution Management in Industries $2^{\text {nd }}$ ed. Karad (India). 1995.

17. K Gerard.EnvironmentalEngineering. McGraw-hall International Editions. 1998.

18. Metcalf and Eddy. Wastewater Engineering Treatment and Reuse. $4^{\text {th }}$ ed. NewYork: McGraw Hill Co. 2003.

19. APHA.Standard methods for the examination of water and waste water. $16^{\text {th }}$ ed. American Public Health Association Washington DC. 1985. 
20. B Srinivasa Reddy,K Venkata Ramana and K Ravindranath,Extraction of Methylene blue dye from polluted waters using some Bio-Adsorbents. Int. J. Appli. Bio. and Pharm. Tehc., 2012, 3: 215-224.

21. HMF Freundlich.Over the ddsorption in solution. J. Phys. Chem., 1906, 57: 385-471.

22. I Langmur. The adsorption of gases on plane surfaces of glass, mica and platinum. J. Am. Chem. Soc. 1918, 40: 1361-1368.

23. MJ Temkin and V Pyzhev. Recent modifications to Langmuir isotherms. ActaPhysiochim. URSS. 1940, 12: 217-222.

24. MM Dubinin andLVRadushKevich. Equation of the Characteristic Curve of Activated Charcoal. Proc. acad. sci. USSR. Phys. chem. sect.1947, 55: 331-333.

25. KR Hall, LC Eagleton, A Acrivo, and TVermevlem. Pore and solid diffusion kinetics in fixed bed adsorption under constant pattern conditions. Ind. Eng. Chem. Fundam., 1966, 5: 212-219.

26. BH Hameed. Evaluation of papaya seeds as a novel non-conventional low-cost adsorbent for removal of methylene blue. J. Hazard. Mater., 2009, 162: 939-944.

27. A Nunes, SA Franca and LS Olievera. Activated carbon from waste biomass: An alternative use for biodiesel production solid residues. Bioresour. Technol., 2009, 100:1786-1792.

28. MS Onyango, Y Kojima, OAoyi, EC Bernardo and $\mathrm{H}$ Matsuda. Adsorption equilibrium modeling and solution chemistry dependence of fluoride removal from water by trivalent-cation-exchanged zeolite F-9.J. Colloid Interface. Sci., 2004, 279: 341-350.

29. J Monika, VGarg and K Kadirvelu. Chromium(VI) removal from aqueous system using Helianthus annuus (sunflower) stem waste. J. Hazard. Mater. 2009, 162: 365-372.

30. P Atkins. Physical chemistry. $6^{\text {th }}$ ed. Oxford University Press, London. 1999; 857-864.

31. S Lagergren. Zurtheorie der sogenannten adsorption gelosterstoffe, Kungliga venska Vetenskapsakademiens. Handlingar. 1898, 24: 1-39.

32. YS Ho and G McKay.Pseudo-second order model for sorption processes. ProcessBiochem. 1999, 34:451465.

33. YS Ho, JCY Ng, and G McKay. Kinetics of pollutant sorption by biosorbents: Review. Sep. Purif. Methods. 2000, 29: 189-232.

34. WJ WeberJr,and JC Morris and J Sanit. Kinetics of Adsorption on Carbon from Solution. J. Sanit. Eng. Div. ASCE1963; 89, 31-59.

35. CAharoni and M Ungarish.Kinetics of activated chemisorption. Part 2.- Theoretical models.J. Chem. Soc. Faraday Trans. 1: Phys Chem Condens Phases. 1977, 73: 456-464.

36. M Ozacar and IA Sengil.A kinetic study of metal complex dye sorption onto pine sawdust. Process Biochem. 2005, 40: 565-572.

37. C Gerente, VKC Lee, P Cloirec and G Le. McKay. Application of chitosan for the removal of metals from wastewaters by adsorption-Mechanisms and Models Review. Crit. Rev. Env. Sci.Tec., 2007, 37: 41-127.

38. G AlagumuthuandMRajan. Kinetic and equilibrium studies on fluoride removal by zirconium (IV): impregnated groundnut shell carbon. Hem Ind. 2010, 64: 295-304.

39. G Karthikeyan and SS Ilango. Fluoride sorption using morringa indica-based activated carbon. Iran. J. Environ. Health. Sci. Eng. 2007, 4:21-28.

40. M Sekar, V. Sakthi and S Rengaraj. Kinetics and equilibrium adsorption study of lead (II) onto activated carbon prepared from coconut shell. $J$ Colloid. Interface Sci., 2004, 279: 307-313.

41. M Horsfall and A Spiff. Effects of temperature on the sorption of $\mathrm{Pb}^{2+}$ and $\mathrm{Cd}^{2+}$ from aqueous solution by Caladium bicolor (Wild Cocoyam) biomass. Electron.J.Biotechnol. 2005;8, 162-169.

42. N Viswanathan and S Meenakshi. Enriched fluoride sorption using alumina/chitosan composite.J. Hazard. Mater. 2010; 178, 226-232.

43. Z Bouberka. S. Kacha, M. Kamecha. S Elmaleh, and Z Derriche. Sorption study of an acid dye from an aqueous solutions using modified clays. J. Hazard. Mater., 2005, 119: 117-124. 
44. K Venkata Ramana, K. Swarna Latha, K. Ravindranath and B. Hari Babu Methyl Red dye removal using New Bio-Sorbents derived from Hyacinth and Tinospora Cordifolia plants from waste waters. Rasayan J. Chem., 2017, 10: 349-362.

45. CS Sundaram, N Viswanathan and S Meenakshi. Defluoridation of water using magnesia/chitosan composite. J. Hazard. Mater. 2009, 163: 618-624.

46. MJ Iqbal and MN Ashiq. Adsorption of dyes from aqueous solutions on activated charcoal. J. Hazard. Mater., 2007, 139: 57-77.

47. AK Chaturvedi, KC Pathak and VN Singh. Fluoride removal from water by adsorption on china clay. Appl. Clay Sci., 1988, 3: 337-346. 